\title{
Development of the Long-Term Morphodynamic Model to Determine the Seawater Intake Location
}

\author{
Lee Hooi Chie ${ }^{1, *}$ Ahmad Khairi Abd Wahab ${ }^{2}$, and Fauzan Kamal Mohd Yapandi ${ }^{3}$ \\ ${ }^{1}$ Civil Engineering Faculty, Universiti Teknologi Malaysia, Malaysia \\ ${ }^{2}$ Center of Coastal and Ocean Engineering, Universiti Teknologi Malaysia, Malaysia \\ ${ }^{3}$ TNB Research (TNBR), Environmental Unit, Malaysia
}

\begin{abstract}
Seawater intake structures are often used at coastal power plant to draw ambient seawater into the cooling system for operation. However, improper selection of water intake location will lead to sediments deposition at the intake structure causing lower intake flow rate, clogging of water filtration devices and reduces the efficiency of the power plant. A 2D process-based model is developed to investigate the morphodynamic behavior of the Kapar coast. The model is developed by coupling the processes of hydrodynamic, waves and sediment transport. The processes are interacted dynamically with bathymetry and lead to the morphological changes. The model is input with the schematisation of seasonal windwave conditions and a representative morphological tide. Morphological acceleration technique is used to simulate the long-term morphodynamic changes with acceptable computational times. Sedimentation and erosion patterns are represented by the model and suitable intake location is determined based on the long-term morphodynamic investigation.
\end{abstract}

\section{Introduction}

Thermal power plants require large quantities of water for cooling which led to the natural choice for locating the plant in the coastal sites where abundant seawater is available. One of the most fundamental criteria to be addressed when evaluating potential power plant site is the access to a reliable supply of consistent-quality seawater. However, the supply of seawater to a power plant is often seems to be relatively straightforward, leading to oversimplification of the factors important to position the water intake structure. The ocean, however, is a dynamic environment with continuous state of change at the seabed, leading to potential sediment problems at the intake if the structure is not properly sited. Sediments carried by the waves and currents will cause severe deposition inside the intake structure. The deposition of the sediments could lead to lower intake flow rate, clogging of water filtration devices causing unacceptable pump operation and reduces the efficiency of the power plant.

\footnotetext{
* Corresponding author: hooichie@gmail.com
} 
A good intake design should place the intake structure at a morphologically stable zone to avoid excessive sediments intrusion.

The main goal of this study is to develop a morphological model to simulate the complex morphodynamics behaviour for seawater intake siting.

A 2D process-based model is developed for this purpose. Process-based models are based on several modules which describe different processes such as hydrodynamic (wave and current) and sediment transport [1]. These modules interact dynamically with bathymetry and lead to the morphological changes. The process-based models have developed rapidly for the past decades and are becoming powerful tools to simulate the morphology of tidal basins and estuaries for different scales [2]. De Vriend and Ribberink (1996) [3] emphasised that each of the relevant processes should be modelled adequately, not only in the sense of process description, but also the combination of the modules in a single model. In a process-based model, the hydrodynamic flow is first calculated on the computational grid where bathymetry, boundary conditions and initial conditions are applied. By using the sediment transport formula (e.g. Van Rijn (1993) [4] and Engelund and Hansen (1967) [5]), sediment transports are calculated following the hydrodynamic flow field. The morphological changes are then determined based on the mass-balance for sediment in each computational grid.

\section{Model approach}

A process-based model was developed based on the finite difference-scheme of Delft3D, which solves the momentum and continuity equations on a curvilinear grid. The governing equations are integrated over depth and shallow water equation is applied. The sediment transport formula of Bijker (1971) [6] is used in this study. The Bijker sediment transport formula is one of the earliest and popular formula used in coastal areas for combined action of currents and waves [7]. The model is set with uniformly mixed bed composition with one layer of sediments which consists of cohesive and non-cohesive sediments. Bedload and suspended load are distinguishing separately in Bijker formula. The bedload transport depends on the total bottom shear stress induced by currents and waves while the suspended load is obtained by integrating the product of vertical velocity profiles and concentration. The reference concentration of the suspended load is expressed as a function of the bedload transport. The Bijker formula appeared to be better than the CERC formula, the Engelund-Hansen formula and Ackers-White formula in coastal engineering practice $[8]$.

The process-based model was developed by coupling the Delft3D-FLOW and Delft3DWAVE modules. Delft3D-FLOW simulates the non-steady flow, sediment transport and morphology [9] while Delft3D-WAVE is applied to simulate the evolution of random, short-crested wind generated waves in coastal waters [10]. Delft3D modelling system has been widely used to study the sediment transport coupled with wave-current modules [11]. The approach adopted for morphological modelling in this study is known as "online approach" [12]. In this approach, the processes of flow, waves, sediment transport and morphological development are updating at all executed time step. The WAVE module will first start the simulation by using the initial conditions and forcing boundary conditions. Then, the resulting wave generated forces are communicated with the FLOW module. FLOW module will start the flow computation by including the wave characteristics for a given number of time steps. After finishing the FLOW computation, the bathymetry, water levels and flow field are fed back to the WAVE module at the given time steps for subsequent wave computation.

The major challenge to develop a long-term morphological model is to couple the modules of different processes in a model, to reach the result with reasonable 
computational time and desired accuracy. To bridge the gap, both morphological acceleration and input reduction techniques are applied in this study. The bed level changes in each computational grid and time step is multiply with the morphological acceleration factor [12]. This approach was tested in some of the practical application [9] [13] [14] and used in the long-term morphological modelling of tidal basins and estuaries [1] [15] [16]. The input reduction technique is achieved by schematizing the major boundary forces which account for seasonal variations of the wind and wave, and fortnightly variations of the tide. Figure 1 shows the overall model approach for this study.

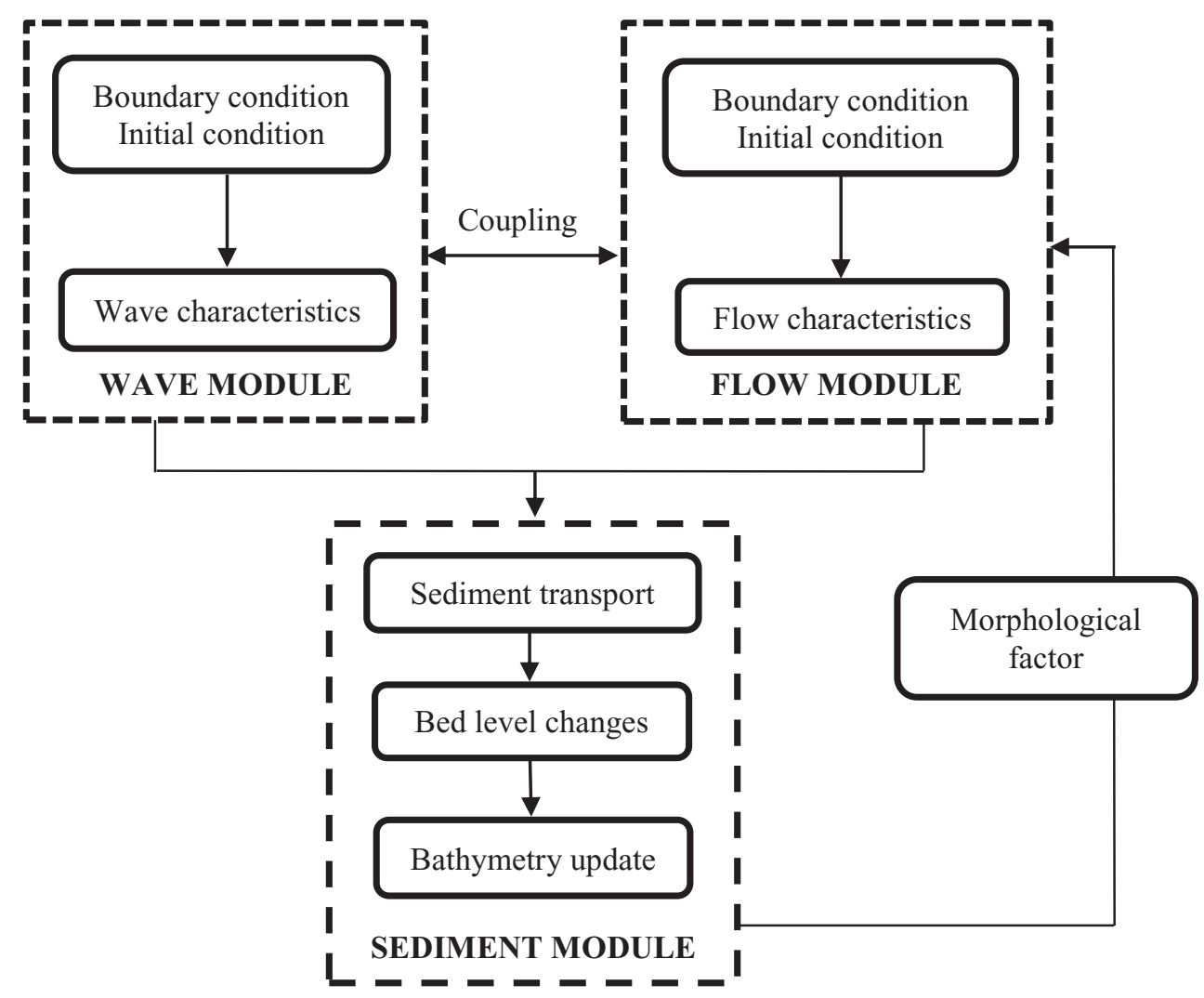

Fig. 1. Model approach

\section{Case study: Kapar coast}

A case study was conducted at Kapar coast to test the ability of the process-based morphological model on predicting the morphodynamic behaviour for seawater intake siting. The Kapar coast is located at the west of Peninsular Malaysia in the middle stretch of Malacca Strait as shown in Figure 2. The Kapar coastline is approximately $13 \mathrm{~km}$ long and is in the Klang District of Selangor, Malaysia. The maximum tidal range recorded at this area is approximately $5.82 \mathrm{~m}$. The spring and neap tidal ranges are $4.11 \mathrm{~m}$ and $1.37 \mathrm{~m}$, respectively. The tide is predominantly semi-diurnal with two high and two low tides occur daily. As shown in Figure 3, the Kapar coastline is generally aligned with approximately 1 $\mathrm{km}$ wide tidal flat. The bathymetry is gently sloping towards Selat Klang Utara navigation channel. The seabed sediments are mainly silty sand near the shore and sandy silt further 
from the shore. Tidal currents flow from north to south during flood tide and south to north during ebb tide as shown in Figure 4. Currents are higher during flood tide compared with ebb tide.

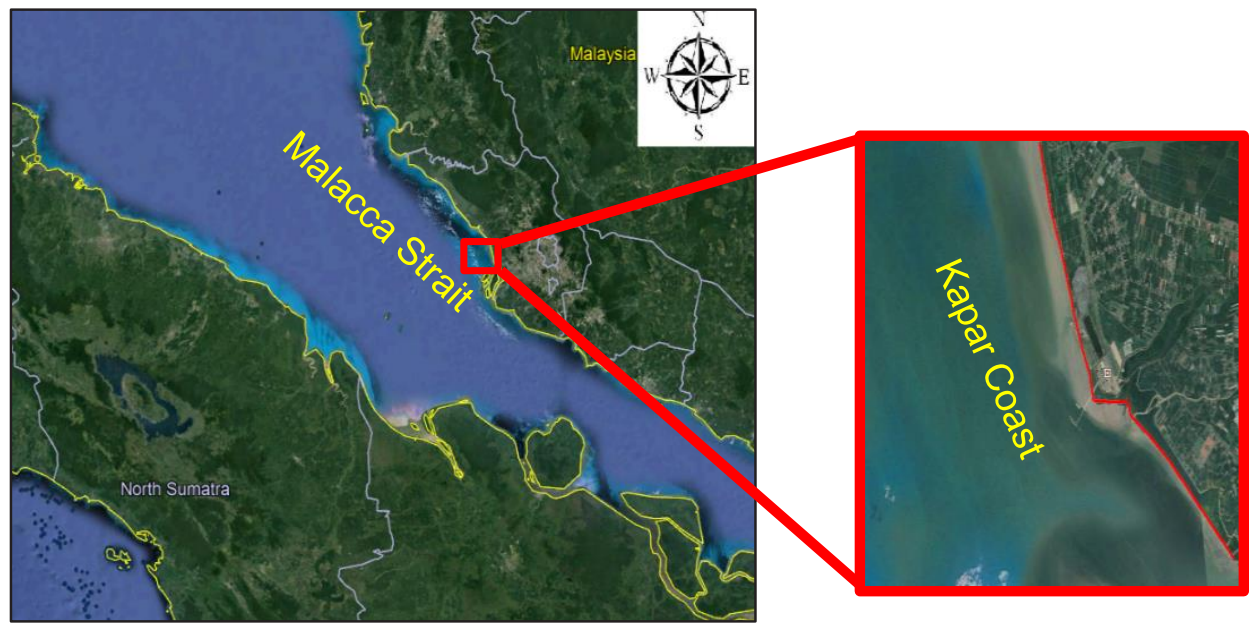

Fig. 2. Location of Kapar coast

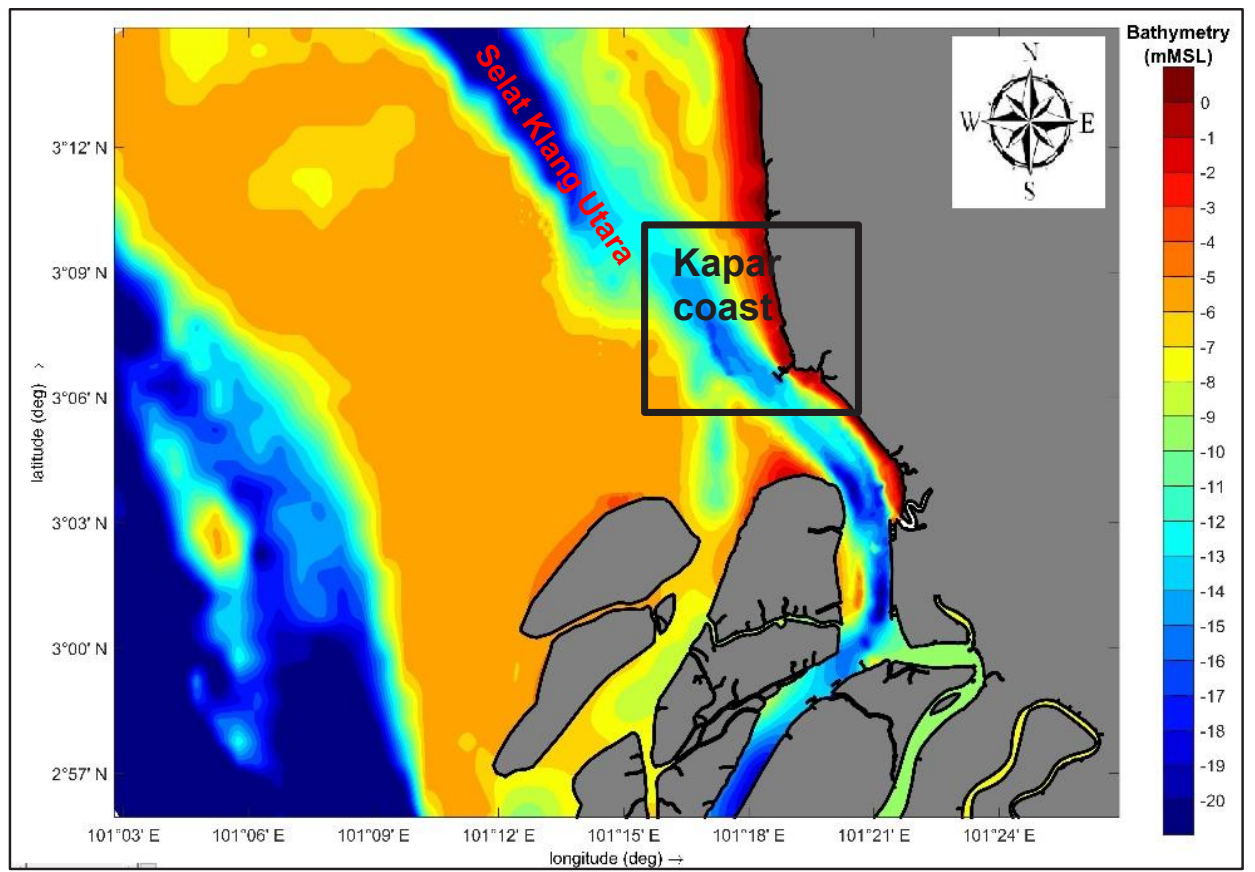

Fig. 3. Bathymetry of the Kapar coast 


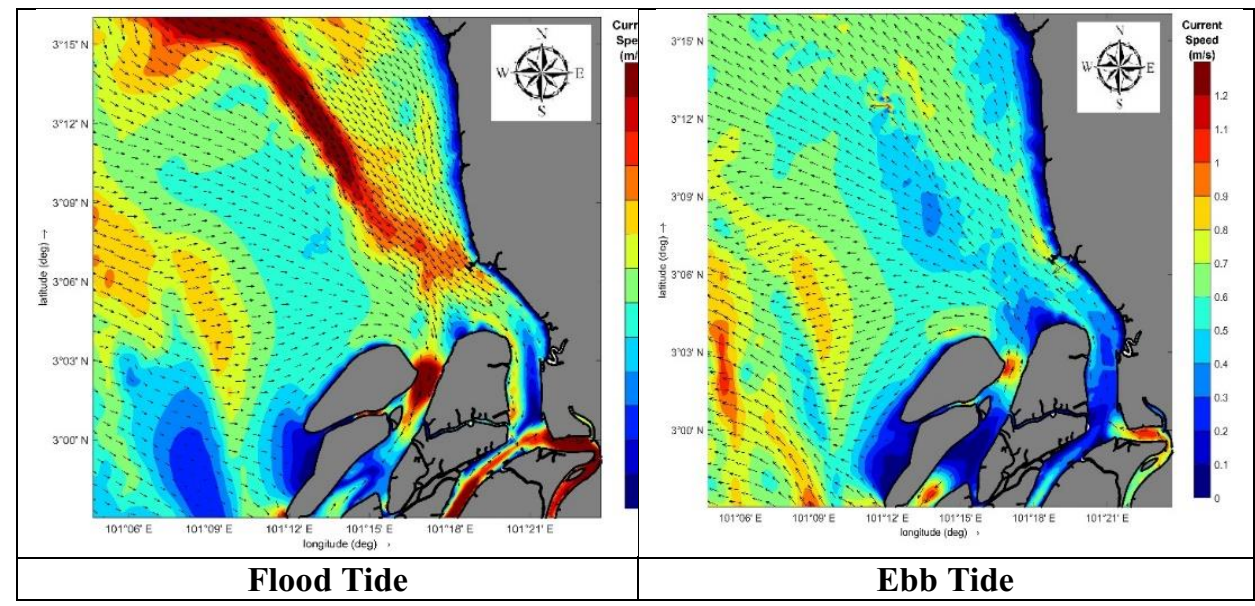

Fig. 4. Typical tidal flows at Kapar coast

\section{Model setup}

A morphological model has been developed for the Kapar coast with tides and waves over a horizon of 10 years. The simulation domain extending from Kuala Selangor to the north and Port Klang to the south (refer Figure 5a). The model grids cover alongshore distance of approximately $50 \mathrm{~km}$ and extended $40 \mathrm{~km}$ seaward with the average grid size of about 130 $\mathrm{m}$. The model domain consists of 288,376 active cells in total. The model domain has 3 open boundaries: two lateral boundaries (North and South) and one seaward boundary as shown in Figure 5b. The lateral boundaries are prescribed as Neumann boundaries, where the alongshore water level gradient is prescribed [17]. The seaward boundary is a water level boundary, forced with a representative morphological tide. The river boundaries were assigned with the discharge flow at $\mathrm{Sg}$. Selangor, Sg. Buloh, Sg. Janggut, Sg. Kapar, Sg. Klang and Sg. Langat as shown in Figure 5c.

\subsection{Morphological tide}

Morphological tide is a schematized tide that replaces the complex time series of tidal water level and induced currents [18] [19]. Latteux's technique [20] is used to develop the morphological tide. Latteux stated that a morphological tide should have the same morphological effect as the real tide to produce the same residual sediment transport and morphological change for the entire spring-neap tidal cycle. In the application of morphological tide with a morphological acceleration factor, random phasing between waves and tides should be especially accounted for. Each of the selected wave condition should be simulated for a full morphological tide [18]. The application of a morphological tide and the simulation of wave conditions over one full morphological tide, in combination with morphological acceleration factor are one of the input reduction technique that strongly benefits the total computation time for long-term morphological modelling [21].

Morphological tide derived in the present study is also based on Lesser's (2009) [18] suggestion to reduce the total set of tidal components to a combination of just two: $\mathrm{M}_{2}$ and $\mathrm{C}_{1}$, in which the amplitude of $\mathrm{C}_{1}=\sqrt{2 O_{1} K_{1}}$ and the phase is $\square_{\mathrm{C} 1}=\frac{\emptyset_{\mathrm{O} 1}+\emptyset_{\mathrm{K} 1}}{2} . \mathrm{A} \mathrm{M}_{2}$ tide with 7$20 \%$ larger amplitude can be considered as the morphological tide in the case of semidiurnal tide [18]. The morphological tide in this study was derived from the TPXO 7.2 
Global Inverse Tide Model in Delft Dashboard, which is a calibrated model for tides in Kapar coast [22].

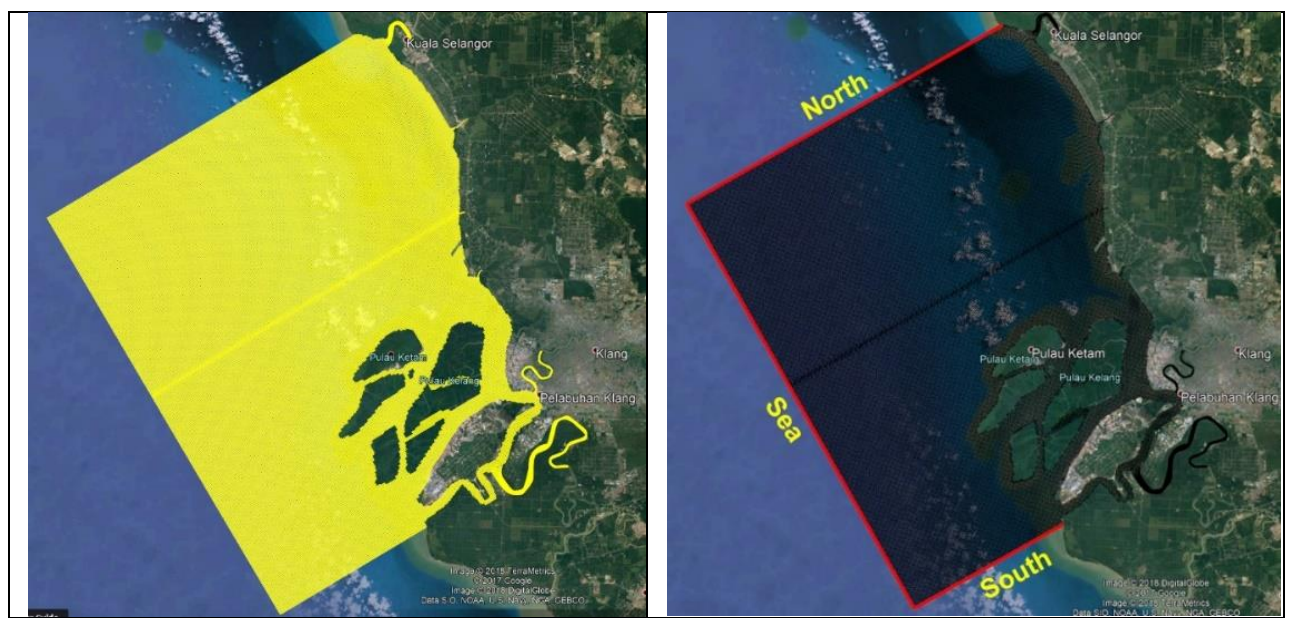

(a) Model Grid

(b) Model Boundary

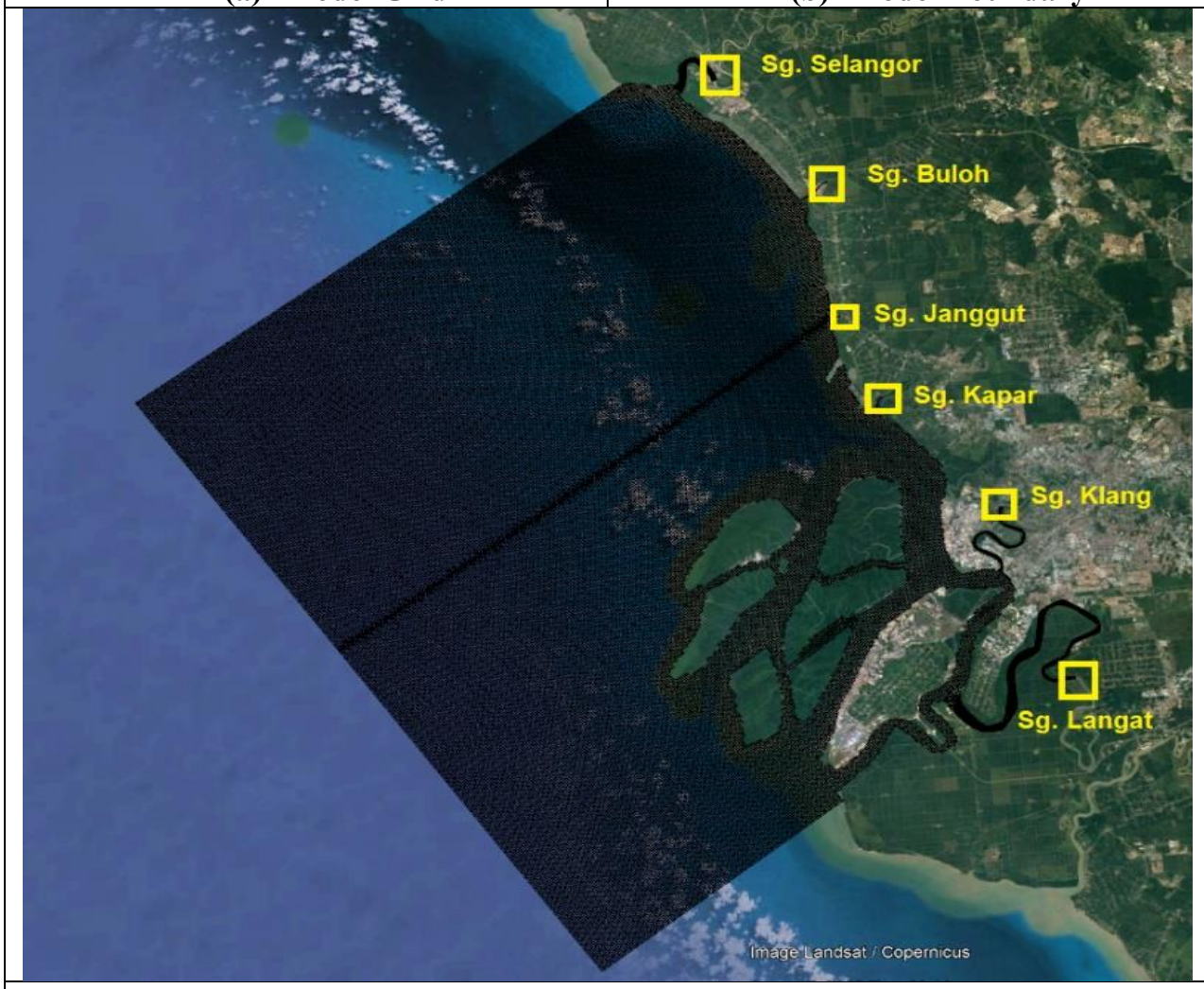

(c) River Boundary

Fig. 5. Model setup for Kapar coast 
The $\mathrm{M}_{2}, \mathrm{O}_{1}$, and $\mathrm{K}_{1}$ harmonic constituents were extracted from the tide model to develop the morphological tide. Table 1 and Table 2 summarized the harmonic constituents used for seaward and Neumann boundaries, respectively to generate the morphological tide.

Table 1: Harmonic constituents for seaward boundary

\begin{tabular}{|c|c|c|c|c|c|}
\hline $\begin{array}{c}\text { Tidal } \\
\text { constituent }\end{array}$ & $\begin{array}{c}\text { Frequency } \\
(\mathbf{\%} / \text { hour) }\end{array}$ & $\begin{array}{c}\text { Amplitude } \\
\text { North (m) }\end{array}$ & $\begin{array}{c}\text { Phase } \\
\text { North (o) }\end{array}$ & $\begin{array}{c}\text { Amplitude } \\
\text { South (m) }\end{array}$ & $\begin{array}{c}\text { Phase South } \\
\mathbf{( \mathbf { } )}\end{array}$ \\
\hline $\mathrm{C}_{1}$ & 14.492052 & 0.1784 & 125.66 & 0.1617 & 129.12 \\
\hline $\mathrm{M}_{1}$ & 28.984104 & 1.6919 & 163.39 & 1.53660 & 147.37 \\
\hline
\end{tabular}

Table 2: Harmonic constituents for Neumann boundary

\begin{tabular}{|c|c|c|c|c|c|}
\hline $\begin{array}{c}\text { Tidal } \\
\text { constituent }\end{array}$ & $\begin{array}{c}\text { Frequency } \\
\text { (\%/hour) }\end{array}$ & $\begin{array}{c}\text { Amplitude } \\
\text { North (m) }\end{array}$ & $\begin{array}{c}\text { Phase } \\
\text { North (o) }\end{array}$ & $\begin{array}{c}\text { Amplitude } \\
\text { South (m) }\end{array}$ & $\begin{array}{c}\text { Phase South } \\
\mathbf{(} \text { ) }\end{array}$ \\
\hline $\mathrm{C}_{1}$ & 14.492052 & $6.62 \mathrm{e}-7$ & 39.12 & $7.73 \mathrm{e}-7$ & 35.66 \\
\hline $\mathrm{M}_{1}$ & 28.984104 & $1.26 \mathrm{e}-5$ & 57.37 & $1.39 \mathrm{e}-5$ & 73.39 \\
\hline
\end{tabular}

\subsection{Wind and wave}

As part of the input reduction technique, the wind-wave climates are also schematized into limited number of representative wind-wave conditions that will produce the same residual sediment transport patterns and rates as the full set of offshore wind-wave conditions. Historical offshore wind-wave data is unavailable in the West Coast of Peninsular Malaysia and therefore, hindcast wind-wave data was used in this study. Directional 3 hours interval wind wave data is available from offshore hindcast point A13198 of British Maritime Technology (BMT) AGROSS database for year 1992 to 2013. The wave energy flux method [23] was used to schematize the wave conditions at the Kapar coast. The energy flux of each wave in the dataset is first calculated using the following equation:

$$
E=\left(\frac{\rho g H_{S}^{2}}{8}\right) \cdot C_{g}
$$

where $\rho$ is the water density $\left(\mathrm{kg} / \mathrm{m}^{3}\right), g$ is the gravitational acceleration $\left(\mathrm{m} / \mathrm{s}^{2}\right), H_{s}$ is the significant wave height $(\mathrm{m})$ and $\mathrm{C}_{\mathrm{g}}$ is the celerity of the deep-water wave group. Then, the wave directions and heights in the dataset are divided into 3 clusters, according to the concept of equal energy so that the sum of energy fluxes in all cluster of waves are equal. The representative wave height in each cluster is calculated based on the average energy flux using the following equation:

$$
H_{S}=\sqrt{\frac{8 E}{\rho g C g}}
$$

The representative wave direction, wind speed and wind direction can be determined by averaging the respective wind-wave condition in each cluster. The schematization of wind-wave climate in this study has accounted for seasonal variations in West Coast of Peninsular Malaysia. The wind-wave data is analyzed based on monthly climate and schematized into 9 representative wind wave conditions for each month. A total of 108 sets of representative wind wave conditions are selected for this study and are illustrated as wave roses in Figure 6. 


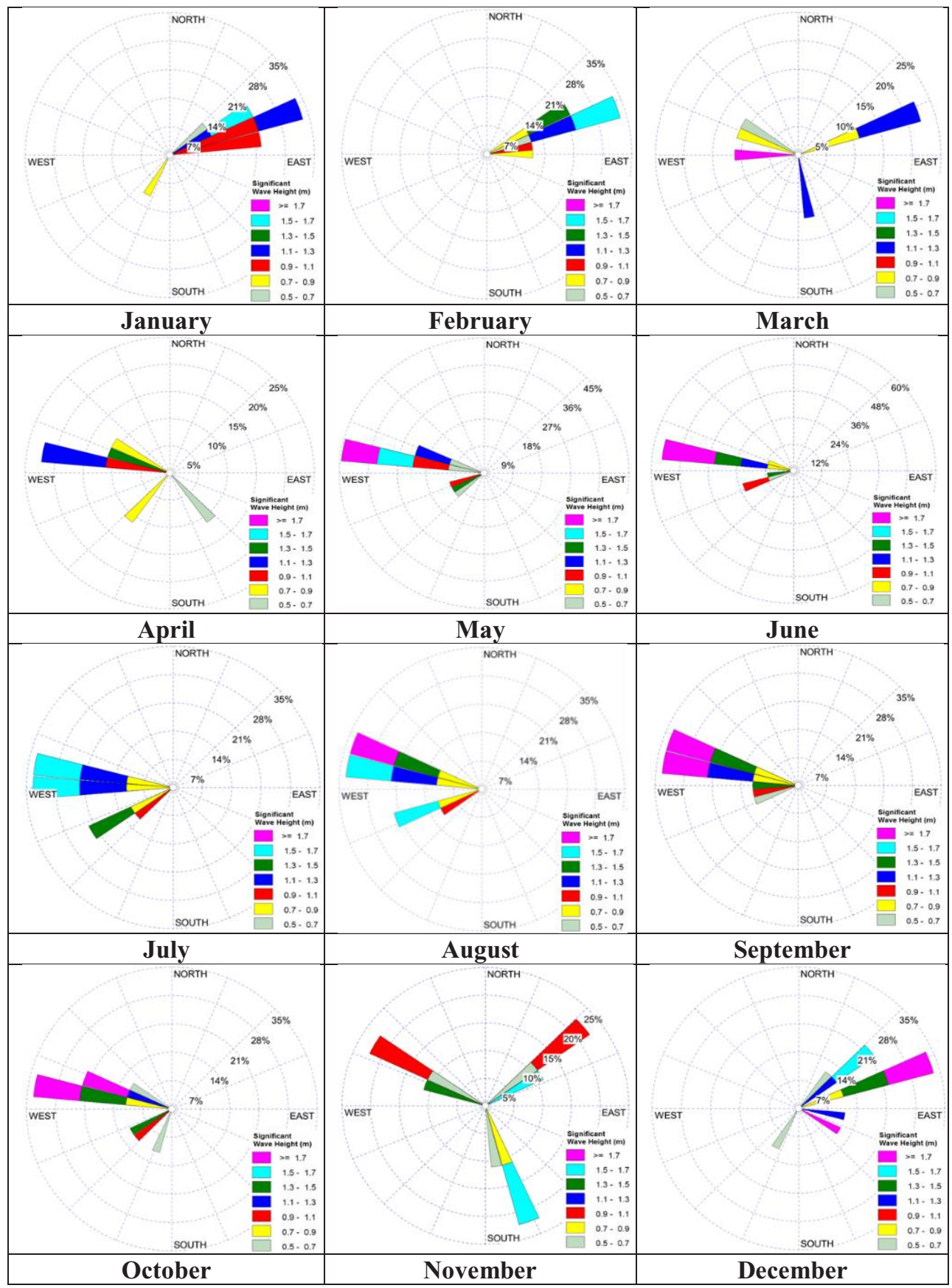

Fig. 6. Representative wave condition selected for each month by Energy Flux Method 


\subsection{Morphological acceleration factor}

The schematized forces (i.e. morphological tide and wind-wave conditions) must be turned into morphological simulation of the required actual time by using Morphological Acceleration Factor (MorFac) with the following equation:

$$
\text { MorFac }=\frac{P_{c} \times T}{T_{\text {mor.tide }}}
$$

where $P_{c}$ is the probability of occurrence of wave condition, $\mathrm{T}$ is the duration of the morphological simulation and $T_{\text {mor.tide }}$ is the hydrodynamic duration of the morphological tide. MorFac is calculated for each representative wave condition so that the morphological duration of each cases matches its probability of occurrence. Each representative wave condition is simulated for a morphological tide of fixed hydrodynamic duration to account for the random phasing between waves and tides.

\section{Result and discussion}

Using the input reduction and morphological acceleration techniques as described in the previous section, a simulation is carried out for a period of 3 years from 2011 to 2013. The simulated results are compared with the findings from the monitoring survey carried out at Northern and Southern zones [24] as indicated in Figure 7. Table 3 compares the findings from both monitoring survey and simulation.

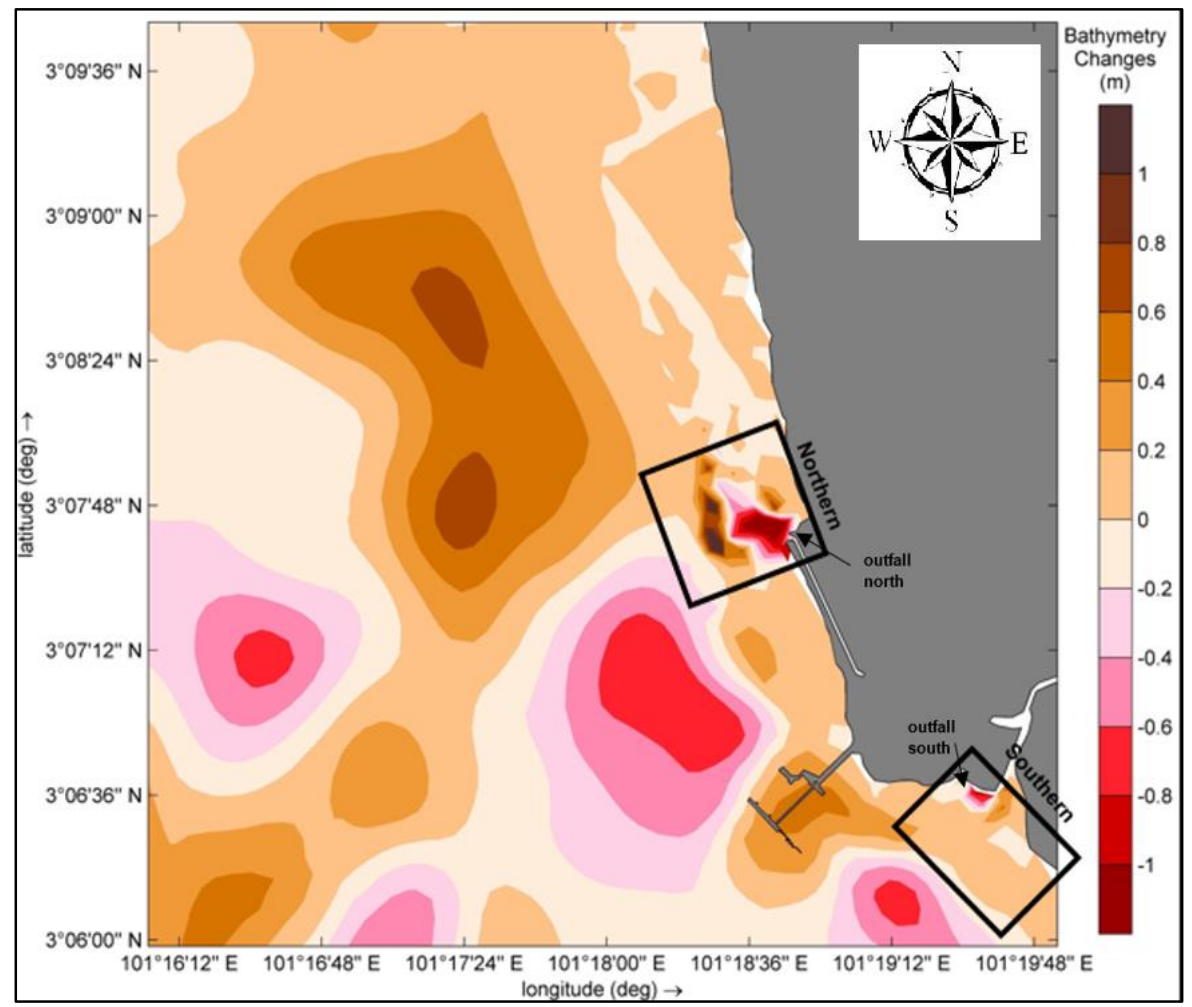

Fig. 7. Modelled morphological changes at Kapar coast from 2011 to 2013 
Table 3: Comparison of the findings from monitoring survey and simulation

\begin{tabular}{|l|l|l|}
\hline $\begin{array}{l}\text { Survey } \\
\text { Area }\end{array}$ & Shoreline Monitoring Survey & Morphological Simulation \\
\hline Northern & $\begin{array}{l}+/-0.3 \mathrm{~m} \text { or lesser change of bed } \\
\text { level }\end{array}$ & $\begin{array}{l}+/-0.4 \mathrm{~m} \text { or lesser change of bed } \\
\text { level }\end{array}$ \\
\hline $\begin{array}{l}\text { Outfall } \\
\text { North }\end{array}$ & accretion of $1 \mathrm{~m}$ on average & sign of accretion of up to $1 \mathrm{~m}$ \\
\hline Southern & $\begin{array}{l}+0.1 \text { to }+0.3 \mathrm{~m} \text { accretion at the } \\
\text { beach area and }+/-0.3 \mathrm{~m} \text { change of } \\
\text { bed level at the foreshore area. }\end{array}$ & $\begin{array}{l}+/-0.3 \mathrm{~m} \text { change of bed level with } \\
\text { exceptional at the outfall south } \\
\text { which show the erosion signs of } \\
\text { between } 0.4 \text { to } 0.8 \mathrm{~m} \text {. }\end{array}$ \\
\hline
\end{tabular}

Visual comparison was conducted (refer to the number indicated in Figure 8) to compare the sedimentation and erosion zones between the satellite image and the modelled morphological changes from year 2006 to 2016. The positive and negative values indicated the sedimentation and erosion patterns, respectively. The comparison results show that the morphology model used in this study is capable of simulating most of the morphological development at the Kapar coast, especially the large-scale sedimentation or erosion patterns.

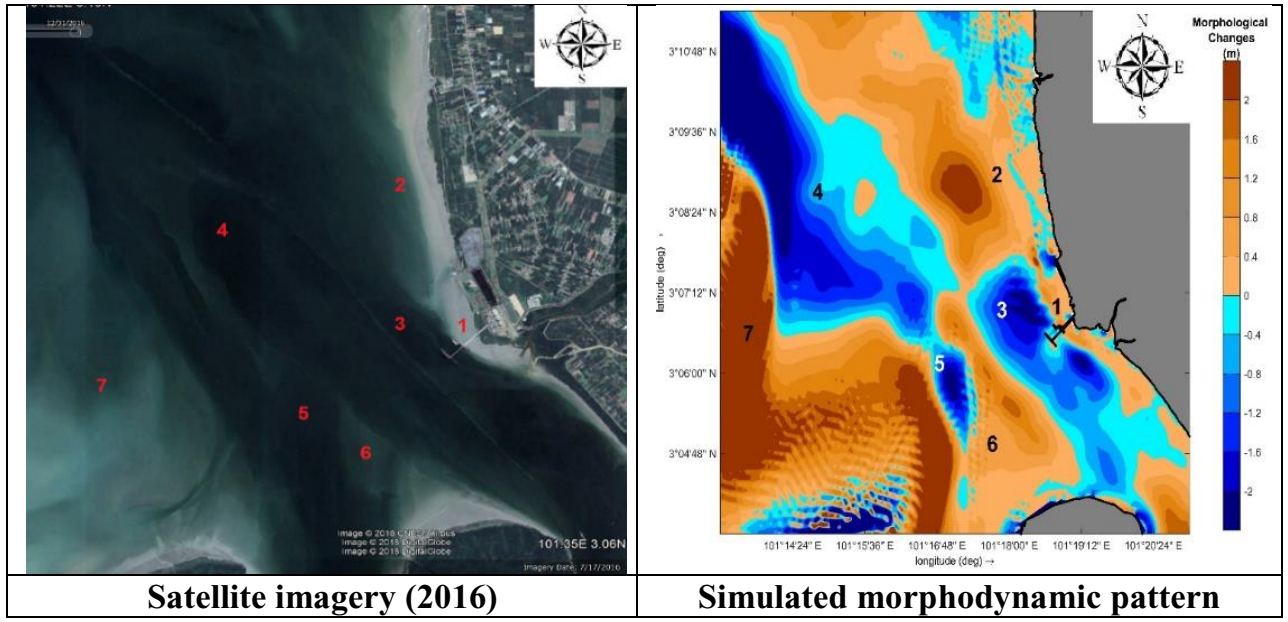

Fig. 8. Visual comparison between the satellite imagery and simulated morphodynamic pattern

A 10 years morphological modelling was conducted to predict the morphodynamic behavior between 2016 to 2026 as shown in Figure 9. From the simulation results, it is noted that:

- It is predicted to experience $+/-0.2 \mathrm{~m}$ change of bathymetry annually at the nearshore area (refer no. 1 in the $1^{\text {st }}$ Year figure). The sediment movement along the shoreline of the Kapar coast is due to the longshore drift. The longshore current carries the sediments up to the beach and back into the sea causing uneven distribution of sediment and erosion patterns along the nearshore zone.

- The backwash transports the sediments from the nearshore zone to deposit at the zone perpendicular to the shoreline at about 0.3 to $3 \mathrm{~km}$ seaward. The sediment deposition of up to $0.4 \mathrm{~m}$ annually can be predicted at this zone (refer no. 2 in the $1^{\text {st }}$ Year figure).

- The area northwestward from the jetty head is predicted to experience erosion of approximately 0.2 to $0.6 \mathrm{~m}$ annually (refer no. 3 in the $1^{\text {st }}$ Year figure). This is probably the breaker zone where the waves approaching the coastline commence breaking. Wave 
breaking generates strong unidirectional currents close to the beach and this is responsible for the transport of sediment to the shore area, causing erosion at this zone.

- It is recommended to locate the intake structure at the mild morphological zone of less than $+/-0.2 \mathrm{~m}$ changes per decade, to avoid potential sediment clogging at the structure (refer no. 4 in the $10^{\text {th }}$ Year figure). The intake structure shall be stabilized with bedding, fill stone, geotextile and armor rock during construction.

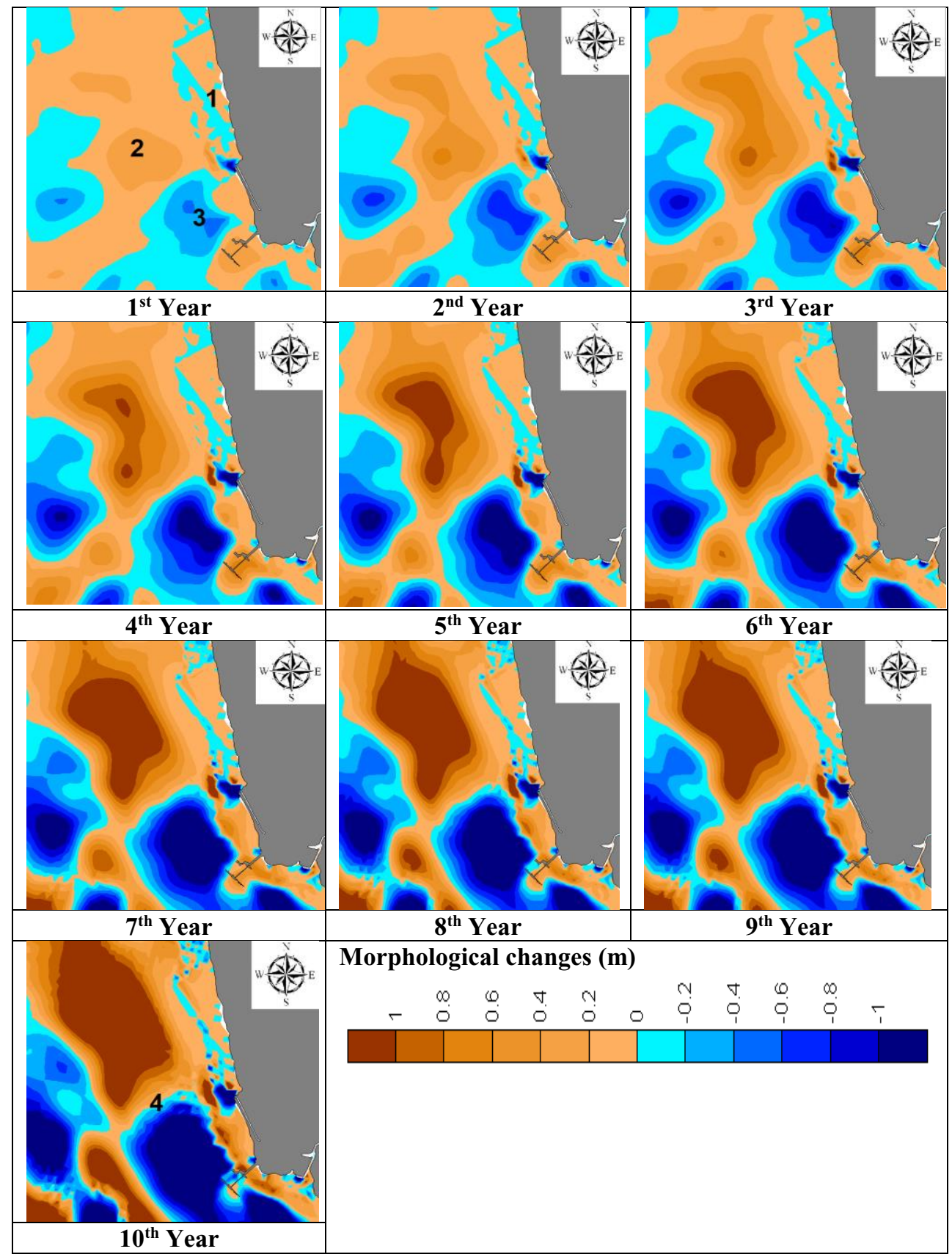

Fig. 9. Predicted 10 years morphological changes at the Kapar coast 


\section{Conclusions}

The results found in this paper demonstrate that the process-based model can be used to simulate long-term morphological changes in the Kapar coast and produce reasonable results for intake structure siting. The morphological model developed in this study is able to reproduce the behavior of main morphological features qualitatively well. For the present technology and our current knowledge, we can conclude that this type of simulations can be used as realistic analogue to better predict the future morphological state of the system in question.

This study starts with the development of morphological model with uniformly wellmixed bed composition. The morphological model produced qualitatively good results but it also revealed the need of more seabed sediment composition and distribution to the model for more realistic results. The performance of the model can be improved significantly by introducing a logical initial sediment size distribution.

The input schematization applied in this study are carried out based on the historical measured and hindcast data, without including the climate change effect. The impacts of climate change, including but not limited to sea level rise and extreme storms, to the morphological evolution in the coastal zone are still arguable. To predict the long-term morphological changes, these influences should be accounted in the input schematization for the process-based morphological model.

Since we are confronted with very limited historical bathymetric data in the Kapar coast, the performance of the model was not evaluated quantitatively. Although the model was evaluated qualitatively by visual comparison, but qualitative method has its own limitation and lack some degree of objectivity. There is a need for more comprehensive recognition algorithms that are able to evaluate the performance of the morphological model with the observations data.

This research would not have been possible without the support of Tenaga National Berhad (TNB) and TNB Research. We thank the specialists from Energy Ventures Division of TNB who provided insight and expertise that greatly assisted the research.

\section{References}

1. D. Ali, Long-Term Process-Based Morphological Modelling of Large Tidal Basins. Doctor Philosophy, Delft University of Technology, Delft, The Netherlands (2012)

2. M. Van der Wegen, and J.A Roelvink, Reproduction of Estuarine Bathymetry by Means of a Process-Based Model: Western Scheldt Case Study, the Netherlands. Geomorphology, 179, 152-167 (2012)

3. H.J De Vriend and J.S Ribberink, Mathemaical Modelling of Meso-Tidal Barrier Island Coasts. Part II: Process-Based Simulation Models. Advances in Coastal and Ocean Engineering, World Scientific Publishing Company, 150-179 Singapore, (1996)

4. Rijn, L.C. van, Principles of Sediment Transport in Rivers, Estuaries aAnd Coastal Seas. Aqua Publications, The Netherlands (1993)

5. F. Engelund, and E. Hansen, A Monograph on Sediment Transport in Alluvial Streams. Teknisk Forlag, Copenhagen, 261-565. (1967)

6. E.W. Bijker, Longshore Transport Computation. Journal of Waterways Harbors Division 97, WW4, Page 687-701 (1971)

7. Deltares, Delft 3D User Manual. (Ver. 3.15.34158), Delft, The Netherlands (2014)

8. J. Van De Graaff,, J. Van Overeem, Evaluation of Sediment Transport Formulae in Coastal Engineering Practice. Coastal Engineering, 3, 1-32. (1979) 
9. G.R. Lesser, J.A. Roelvink, J.A.T.M. van Kester and G.S. Stelling, Development and Validation of a Three-Dimensional Morphological Model. Coastal Engineering, 51, 89, pp 883-915 (2004)

10. N. Booij, R.C Ris, and L.H. Holthuijsen, A Third-Generation Wave Model for Coastal Regions. Part 1: Model description and validation. Journal of Geophysical Research, 104, C4, 7649-7666 (1999)

11. R. Mayerle,, R Narayanan,, T. Etri, and A.K, Wahab, A Case Study of Sediment Transport in the Paranagua Estuary Comples in Brazil. Journal of Ocean Engineering, 106, 161-174, (2015)

12. Roelvink, J.A.. Coastal Morphodynamic Evolution Techniques. Coastal Engineering, 53, 277-287, (2006)

13. G.R. Lesser, J.H. De Vroeg, J.A. Roelvink, M. De Gerloni,. And V. Ardone, Modelling the Morphological Impact of Submerged Offshore Breakwater. Proc. Coastal Sediments, 3 (2003)

14. J.A. Roelvink, T. Van Kessel,, S. Alfageme, and R. Canizares,, Modelling of barrier island response to storms. Proc. Coastal Sediments, 3 (2003)

15. M. Van der Wegen, and J.A. Roelvink, Long-Term Estuarine Morphodynamic Evolution of a Tidal Embayment Using a 2 Dimensional Process Based Model. Journal of Geophysical Research, 113, C03016, (2008)

16. M. Van der Wegen, Z.B. Wang, , H.H.G. Savenije, and J.A Roelvink., Longterm Morphodynamic Evolution and Energy Dissipation in a Coastal Plain and Tidal Embayment. Journal of Geophysical Research, 113, F03001. (2008)

17. J.A. Roelvink, and D.J.R. Walstra, Keeping it Simple by Using Complex Models. In Proceedings of the 6th International Conference on Hydro-Science and Engineering (ICHSE 2004). Advances in Hydro-Science and Engineering, 6, 12. Brisbane, Australia (2004)

18. G.R. Lesser, An Approach to Medium-Term Coastal Morphological Modelling. PhD Thesis, UNESCO-IHE \& Delft University of Technology, Delft. CRC Press/Balkema (2009)

19. N.M. Grunnet,, D.J.R. Walstra,, B.G. Ruessink, Process-Based Modelling Of A Shoreface Nourishment. Coastal Engineering, 51, 581-607,(2004).

20. B. Latteux, Techniques for Long-Term Morphological Simulations under Tidal Action. Marine Geology 126, 129-141, (1995)

21. E. Moerman, Long-Term Morphological Modelling of the Mouth of the Columbia River. Msc Thesis, Delft University of Technology, The Netherlands (2011)

22. H.C. Lee, Cost Effective Solution for Cooling Water System of Thermal Power Plant To Reduce The Impacts of Sedimentation and Thermal Plume Discharges to the Marine Environment at Kapar Coastal Area. unpublished report submitted to TNB Research, G\&P Water \& Maritime Sdn Bhd (2014)

23. J.P.H. Dobrochinski, Wave Climate Reduction and Schematization for Morphological Modelling. MSc Thesis, Delft University of Technology (2009)

24. Kapar Energy Ventures Sdn Bhd. Shoreline Monitoring Report No.6 Final Shoreline Monitoring Report. unpublished report submitted to Jabatan Pengairan dan Saliran (JPS) (2013) 